\section{Response to: 'Less antibiotics but no inferior effect for bacterial arthritis' by Zhang et al}

We read with great interest the scientific remarks of our colleagues Zhang et al ${ }^{1}$ to our article, ${ }^{2}$ randomising to either two or 4 weeks of systemic targeted antibiotic therapy after surgical drainage of native joint bacterial arthritis in adults. This was a classical non-inferiority trial advocating a similar outcome, similar mechanical sequels and a similar proportion of antibioticrelated adverse events in the short-antibiotic treatment group when compared with the classical long antibiotic administration of 4 weeks. However, trial was sufficiently powered for the subgroup of hand and wrist arthritis cases. It was not for other possible separate subsets of septic arthritis episodes such as hip, knee, elbows and others. ${ }^{2}$ Our colleagues Zhang et al equally acknowledge this inherent shortcoming of every arthritis trial. ${ }^{1}$

Additionally, Zhang et al ask for some worthwhile issues that were not discussed. Their four questions concern the low proportion of arthroscopic lavages, the possibility of an initial intravenous large-spectrum empirical antibiotic use, the lack of antibiotic susceptibility results for the pathogens of pet bites and the fact that radiology was not required to rule out osteomyelitis.

We did not design the trial regarding the question which antibiotic agent should be preferred or which lavage technique should be performed. Consequently, the different surgeons were free to decide how and when they debride. In our setting, the arthroscopic procedure, at least for hand surgery, is obviously not en vogue.

Regarding the antibiotic choices and the susceptibility pattern, we would like to clarify eventual misunderstandings. The different clinicians were allowed to choose the empirical (and parenteral) antibiotic among a list of possible agents. In this list, there were equally broad-spectrum agents. In reality, only vancomycin was used in four episodes, ${ }^{2}$ which was the broadest agent. Overall, the most common agent was co-amoxiclav (in 145 cases!), which perfectly covered all bites (almost all Pasteurella spp; streptococci or Eikenella). Very rarely, P. multocida was reported being resistant to co-amoxiclav according to standard laboratory testing (which we did not reconfirm), in which case the alternatives were quinolones.

Finally, we excluded arthritis episodes with concomitant established osteomyelitis and said that 'abnormal radiological images were not required'. Nota bene, the images were not required for arthritis. The exclusion of an established chronic osteomyelitis with bone deformities, sequesters or sinus tracts could be suspected by history or intraoperatively. If there was a formal acute osteomyelitis without established bone lesions (eg, a tiny undetected hole by a recent cat bite), we could not recognise this and treated as if there was no osteomyelitis. We think that we were right, because the clinical recurrences were not osteomyelitis, but still septic arthritis cases. Lastly, as the majority of our patients were traumatic, most did have a standard radiological examination to exclude fractures but not routinely for the radiological confirmation of clinical septic arthritis.

\section{Ilker Uçkay $\odot{ }^{1}{ }^{1}$ Ergys Gjika ${ }^{2}$}

${ }^{1}$ Uniklinik Balgrist, Zurich, Switzerland

${ }^{2}$ Geneva, Switzerland

Correspondence to Dr Ilker Uçkay, Uniklinik Balgrist, Zurich 8008, Switzerland; ilker.uckay@balgrist.ch

Handling editor Josef S Smolen

Contributors Both authors: writing of the response.

Competing interests None declared.

Patient consent for publication Not required.

Provenance and peer review Commissioned; internally peer reviewed.

(c) Author(s) (or their employer(s)) 2020. No commercial re-use. See rights and permissions. Published by BMJ.

\section{Check for updates}

To cite Uçkay I, Gjika E. Ann Rheum Dis 2020;79:e145.

Received 20 June 2019

Accepted 22 June 2019

Published Online First 5 July 2019

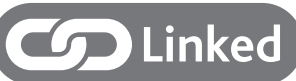

http://dx.doi.org/10.1136/annrheumdis-2019-215682

Ann Rheum Dis 2020;79:e145. doi:10.1136/annrheumdis-2019-215909

ORCID iD

Ilker Uçkay http://orcid.org/0000-0002-5552-0973

\section{REFERENCES}

1 Tian J, Cheng C, Zhang F. Less antibiotics but no inferior effect for bacterial arthritis. Ann Rheum Dis 2020;79:e144.

2 Gjika E, Beaulieu J-Y, Vakalopoulos K, et al. Two weeks versus four weeks of antibiotic therapy after surgical drainage for native joint bacterial arthritis: a prospective, randomised, non-inferiority trial. Ann Rheum Dis 2019;78:1114-21. 